\title{
New Improved Maximum Power Point Tracking Algorithm for Partially Shaded PV Systems
}

\author{
Dmitry Baimel ${ }^{1}$, Saad Tapuchi ${ }^{1}$, Nina Baimel ${ }^{2}$ \\ ${ }^{1}$ Shamoon College of Engineering, Beer-Sheva, Israel \\ ${ }^{2}$ Sapir Academic College, Hof Ashkelon, Israel \\ Email:dmitrba@sce.ac.il
}

How to cite this paper: Baimel, D., Tapuchi, S. and Baimel, N. (2017) New Improved Maximum Power Point Tracking Algorithm for Partially Shaded PV Systems. Journal of Power and Energy Engineering, 5, 55-63.

https://doi.org/10.4236/jpee.2017.59005

Received: June 19, 2017

Accepted: September 12, 2017

Published: September 15, 2017

Copyright $\odot 2017$ by authors and Scientific Research Publishing Inc. This work is licensed under the Creative Commons Attribution International License (CC BY 4.0).

http://creativecommons.org/licenses/by/4.0/

\begin{abstract}
The paper presents new MPPT algorithm for partial shading of series connected PV cells/modules. In the shaded condition, there is a problem of decrease in the total output power of the PV system. The proposed algorithm aims to reduce this problem by active bypassing of the shaded cells. The algorithm senses the irradiance of each cell and performs calculation in order to decide if to actively bypass the shaded cell or not. Extensive simulation results proved that algorithm works and increases the output power under partial shading conditions. Furthermore, the algorithm becomes more efficient when the number of cells is increased.
\end{abstract}

\section{Keywords}

MPPT, Algorithm, Partial Shading, Simulation

\section{Introduction}

There is a constant increase in worldwide electrical power consumption and the conventional energy resources are limited. As a result, the need for renewable energy sources is constantly increasing. The photovoltaic (PV) systems draw special attention as one of the most promising renewable energy sources due to the fact that solar energy is clean, inexhaustible, without pollution and can be easily harvested. The PV panels convert solar energy into electrical energy.

The PV panels can be used as standalone electric power sources or integrated to the main grid as additional power source. The total cost of the PV system depends on the cost of PV array and the area it catches.

The solar cell, in terms of an electrical source, acts as a current source. The light hits the solar cell surface and as a result the solar cell produces current [1]. The PV systems have drawbacks of electric parameters and power generation varia- 
tion with irradiation level and temperature changes. These variations influence short-circuit current, the open-circuit voltage, the Fill Factor (FF), the efficiency etc. [2]. Another important disadvantage is low conversion efficiency of the PV panels.

Often, PV modules are shaded fully or partially due to few reasons like movement of clouds, adjacent high buildings, trees and the movement of the sun itself [3]-[9]. This shading leads significant reduction in the output power and internal devastating effects.

During partial shading, the PV curve of the array has multiple maximum points-several local peaks and one global peak. This can lead to the situation where the local peak is mistakenly recognized by the MPPT algorithm as a maximum point instead of true global peak in this case the system will operate at this local peak and significant power losses will be present [10] [11]. Therefore, the $\mathrm{PV}$ system has been operated at the real global maximum power point in all conditions, including during partial shading.

The standard MPPT methods can't identify the real global peak during the partial shading because they are not sophisticated enough to differentiate between the local and global points. The standard MPPT methods can be divided into two categories: direct and indirect tracking. The direct tracking methods have the advantage of being independent from prior knowledge of PV characteristics. Thus, the operation point is independent of isolation, temperature or degradation levels. The most common direct tracking methods are Incremental Conduction (IC) [12], Perturb and Observe (PO) [13] [14], as well as neural network and fuzzy logic techniques [15] [16] [17]. The indirect tracking methods use databases of parameters that include empirical data of typical P-V curves for different irradiances and temperatures, or use mathematical functions obtained from the empirical data to estimate the MPP [18] [19]. The direct tracking methods include the techniques of look-up table, open circuit PV voltage and short circuit PV current and more. The MPPT methods are implemented by insertion of DC-DC converter between the PV panel and the load [20] [21]. The switching of DC-DC converter is controlled by MPPT algorithms by Pulse Width Modulation (PWM).

The simplest solution is using by-pass diodes and inverters, which track the maximum power point, thus keeping the cells safe and utilize them. However, this solution has a limited effectiveness due to the fact that one inverter can draw just one current from all the modules. If one of them is shaded it can't be utilized in full potential. On the other hand, the use of inverter for each module increases costs.

Additional methods were reported in the literature [22] [23] [24] [25] [26]. They have some drawbacks such as limited application (not appropriate for all limited conditions), slow response and computationally complicated.

\section{The Benefits of the Bypassing PV Modules during Partial Shading}

In order to understand the processes that happen during partial shading of dif- 
ferent PV cells, two PV arrays each consisted of ten series connected cells. Each module has parallel diode for bypassing. The load of the PV system is implemented by the voltage source. The simulated model is shown in Figure 1. Different cases of irradiation combinations were simulated and the total output power of the PV system was calculated. The simulation results are concentrated in Table 1. Table 2 shows simulated output power of the PV system consisted of only one PV module.

During the shading the irradiance on each module is different and this causes the output power reduction of the whole PV system. For some irradiance conditions, the output power of the whole system will be smaller than the output power of one cell. This conclusion is seen from comparison between the values in Table 1 and Table 2. In these cases, it is preferable to bypass cell in order to increase the output power. These cases are colored in red in the Table 1. For example, when the irradiance of two modules is 1000/2 and 450/2 the obtained output power is $16.31 \mathrm{~W}$ (see Table 1 ) and if the module with $450 / 2$ is by-passed, the output power will rise to $16.8 \mathrm{~W}$ (see Table 2). This effect will become even more complicated when the number of the PV cells connected in series is increased.

\section{The Proposed Method}

The paper proposes method that performs active bypassing of the modules by switches (Figure 2). In Figure 2, each PV cell has parallel bypass switch that can be closed in order to bypass the cell in the case of cell shading.

The typical P-V curve for PV system with three cells is shown in Figure 3.

During the partial shading, the most shaded module will has the lowest current that will limit the current of the whole string due to the series connection of the modules. The proposed algorithm checks if it is more efficient to bypass the most shaded module or not. The flowchart of the algorithm is shown in Figure 4.

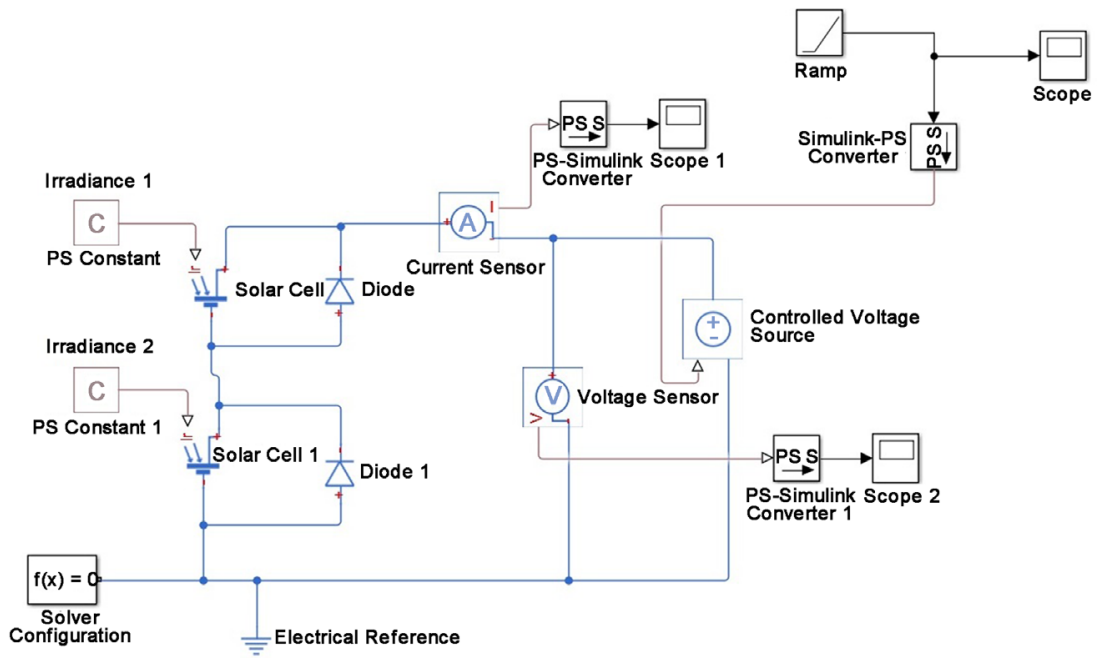

Figure 1. The simulated PV system for output power calculation for different cases of irradiation and shading. 
Table 1. The simulated output power of the PV system for different irradiance conditions, two PV modules.

\begin{tabular}{|c|c|c|c|c|c|c|c|c|c|c|c|c|c|c|c|c|c|c|c|c|}
\hline 11Irr & 1000 & 950 & 900 & 850 & 800 & 750 & 700 & 650 & 600 & 550 & 500 & 450 & 400 & 350 & 300 & 250 & 200 & 150 & 100 & 50 \\
\hline 1000 & 33.61 & 32.58 & 31.31 & 29.87 & 28.34 & 26.73 & 25.07 & 23.37 & 21.64 & 19.88 & 18.1 & 16.31 & 14.49 & 12.68 & 12.36 & 12.17 & 11.98 & 11.79 & 11.6 & 11.44 \\
\hline 900 & 31.31 & 30.82 & 30.1 & 29.06 & 27.76 & 26.3 & 24.74 & 23.1 & 21.42 & 19.71 & 17.96 & 16.19 & 14.41 & 12.6 & 11.35 & 11.18 & 11.01 & 10.84 & 10.67 & 10.5 \\
\hline 850 & 29.87 & 29.53 & 29.06 & 28.35 & 27.3 & 25.99 & 24.51 & 22.94 & 21.29 & 19.6 & 17.88 & 16.12 & 14.35 & 12.56 & 10.82 & 10.66 & 10.5 & 10.34 & 10.18 & 10.01 \\
\hline 800 & 28.34 & 28.09 & 27.76 & 27.3 & 26.6 & 25.54 & 24.21 & 22.73 & 21.13 & 19.48 & 17.78 & 16.05 & 14.29 & 12.52 & 10.72 & 10.13 & 9.98 & 9.83 & 9.67 & 9.52 \\
\hline 750 & 26.73 & 26.53 & 26.3 & 25.99 & 25.54 & 24.85 & 23.79 & 22.44 & 20.94 & 19.33 & 17.67 & 15.96 & 14.22 & 12.46 & 10.68 & 9.59 & 9.44 & 9.3 & 9.16 & 9.01 \\
\hline 700 & 25.07 & 24.92 & 24.74 & 24.51 & 24.21 & 23.79 & 23.11 & 22.04 & 20.68 & 19.15 & 17.53 & 15.86 & 14.14 & 12.4 & 10.63 & 9.02 & 8.89 & 8.75 & 8.62 & 8.48 \\
\hline 650 & 23.37 & 23.24 & 23.1 & 22.93 & 22.73 & 22.44 & 22.04 & 21.37 & 20.29 & 18.9 & 17.37 & 15.74 & 14.05 & 12.34 & 10.58 & 8.82 & 8.33 & 8.2 & 8.07 & 7.95 \\
\hline 550 & 19.88 & 19.8 & 19.71 & 19.6 & 19.48 & 19.33 & 19.15 & 18.9 & 18.54 & 17.91 & 16.8 & 15.06 & 13.81 & 12.16 & 10.46 & 8.72 & 7.15 & 7.04 & 6.94 & 6.83 \\
\hline 500 & 18.1 & 18.04 & 17.96 & 17.88 & 17.78 & 17.67 & 17.53 & 17.37 & 17.14 & 16.8 & 16.19 & 14.47 & 13.62 & 12.04 & 10.37 & 8.67 & 6.91 & 6.44 & 6.34 & 6.25 \\
\hline 450 & 16.31 & 16.25 & 16.19 & 16.13 & 16.05 & 15.96 & 15.86 & 15.74 & 15.58 & 15.38 & 15.06 & 14.17 & 13.34 & 11.88 & 10.28 & 8.59 & 6.88 & 5.83 & 5.74 & 5.66 \\
\hline 400 & 14.5 & 14.45 & 14.4 & 14.35 & 14.29 & 14.23 & 14.05 & 14.05 & 13.95 & 13.81 & 13.62 & 13.34 & 12.76 & 11.61 & 10.12 & 8.51 & 6.83 & 5.21 & 5.13 & 5.05 \\
\hline 350 & 12.68 & 12.65 & 12.61 & 12.56 & 12.52 & 12.46 & 12.4 & 12.33 & 12.26 & 12.16 & 12.04 & 11.87 & 11.61 & 11.07 & 9.89 & 8.38 & 6.75 & 5.07 & 4.5 & 4.43 \\
\hline 300 & 12.36 & 11.86 & 11.35 & 10.82 & 10.72 & 10.68 & 10.64 & 10.58 & 10.52 & 10.47 & 10.37 & 10.27 & 10.12 & 9.89 & 9.38 & 8.18 & 6.66 & 5.01 & 3.86 & 3.8 \\
\hline 250 & 12.17 & 11.68 & 11.18 & 10.66 & 10.13 & 9.59 & 9.02 & 8.82 & 8.77 & 8.72 & 8.67 & 8.59 & 8.51 & 8.38 & 8.19 & 7.72 & 6.49 & 4.93 & 3.29 & 3.16 \\
\hline 200 & 11.98 & 11.5 & 11.01 & 10.5 & 9.98 & 9.44 & 8.89 & 8.33 & 7.74 & 7.15 & 6.93 & 6.88 & 6.83 & 6.75 & 6.65 & 6.49 & 6.07 & 4.81 & 3.24 & 2.51 \\
\hline 150 & 11.79 & 11.32 & 10.84 & 10.34 & 9.83 & 9.3 & 8.75 & 8.2 & 7.63 & 7.04 & 6.44 & 5.83 & 5.21 & 5.07 & 5.01 & 4.94 & 4.081 & 4.55 & 3.16 & 1.86 \\
\hline 50 & 11.41 & 10.96 & 10.5 & 10.01 & 9.52 & 9.01 & 8,48 & 7.95 & 7.4 & 6.83 & 6.25 & 5.66 & 5.05 & 4.43 & 3.8 & 3.16 & 2.51 & 1.86 & 1.53 & 1.35 \\
\hline
\end{tabular}

Table 2. The simulated output power of the PV system for different irradiance conditions, one PV module.

\begin{tabular}{rrrrrrrrrrrrrrrrrrrrrrrrrr}
\hline 1000 & 950 & 900 & 850 & 800 & 750 & 700 & 650 & 600 & 550 & 500 & 450 & 400 & 350 & 300 & 250 & 200 & 150 & 100 & 50 & \\
16.8 & 15.93 & 15.05 & 14.17 & 13.29 & 12.42 & 11.55 & 10.69 & 9.82 & 8.95 & 8.07 & 7.23 & 6.38 & 5.53 & 4.69 & 3.84 & 3.03 & 2.23 & 1.42 & $57 \gamma 0$ \\
\hline
\end{tabular}

The main principle of the proposed method relies on the measurement of the irradiance of each PV module. By knowing the irradiance and the I-V curves, the possible output current of each cell is calculated. The cell with the lowest possible current is the most shaded cell. The algorithm locates this cell. Afterwards, the total output power of the PV system $\left(P_{\text {out }}\right)$ is calculated by:

$$
P_{\text {out }}=I_{\text {out }} * n * V_{\text {cell }}
$$

where $n$ is the number of series connected cells, $V_{\text {cell }}$ is the output voltage of each cell and $I_{\text {out }}$ is the current of the PV module. The next step is to calculate the new output power of the PV system $\left(P_{\text {out_new }}\right)$ if the most shaded cell is bypassed.

In this case there will be $(n-1)$ cells:

$$
P_{\text {out_new }}=I_{\text {out_new }} *(n-1) * V_{\text {cell }}
$$




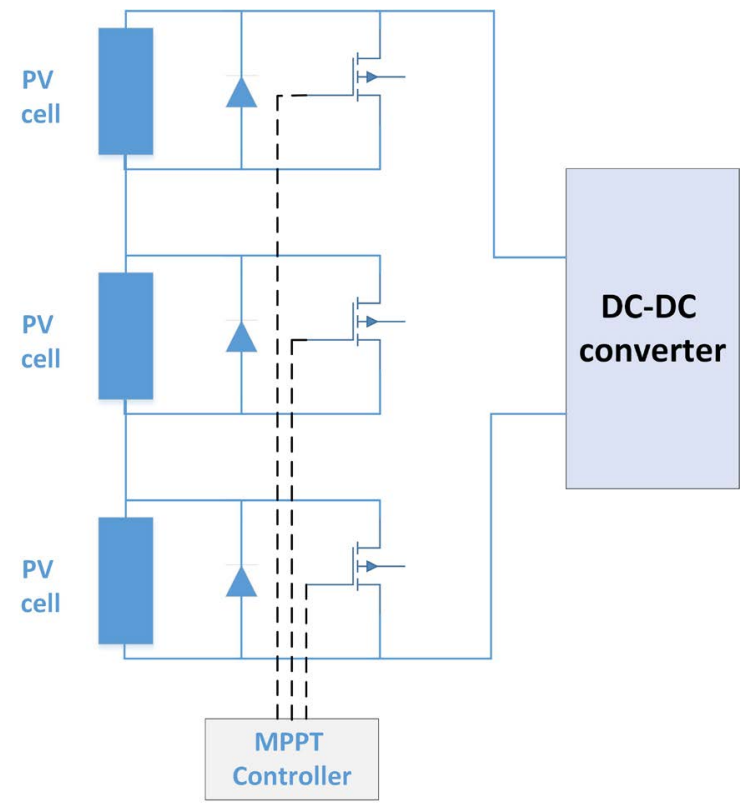

Figure 2. Active bypassing.

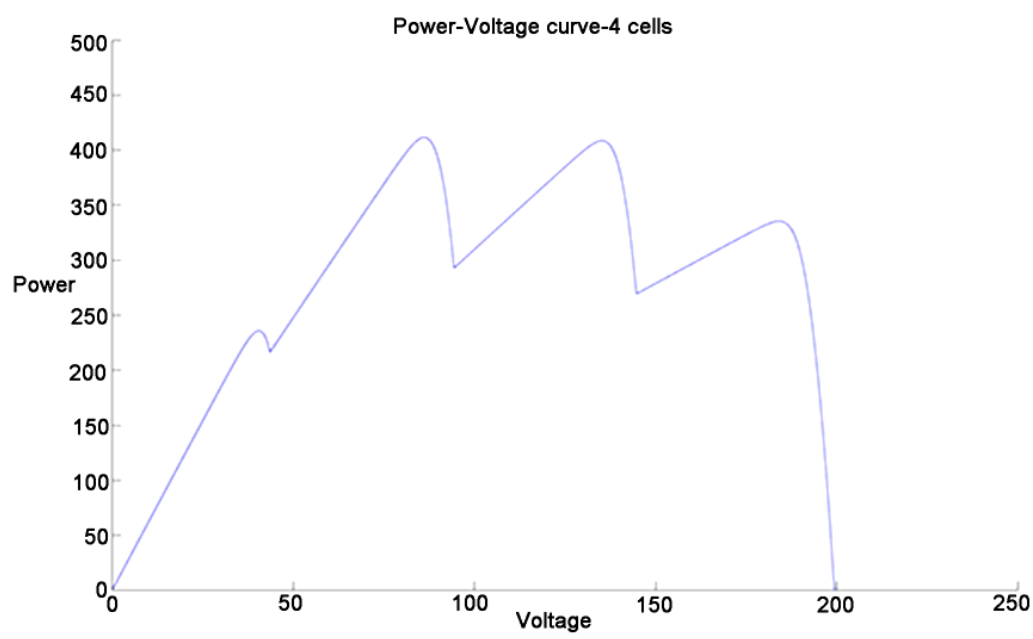

Figure 3. Typical I-V curve during partial shading [27], three PV modules are present in the system.

where $I_{\text {out_new }}$ is the new obtained P module current due to the bypassing the shaded cell.

Then, the algorithms checks if the new output power with bypass is higher than the original output power including the switching losses of the switch $P_{\text {loss }}$ :

$$
P_{\text {out_new }}>P_{\text {out }}+P_{\text {loss }}
$$

If true, then the most shaded cell is bypassed by parallel switch. At the end of cycle the algorithm returns to the beginning.

\section{Simulation Results}

The proposed algorithm is tested on two series connected PV cells with parallel bypass switches (see Figure 5). The load was chosen as variable voltage source 


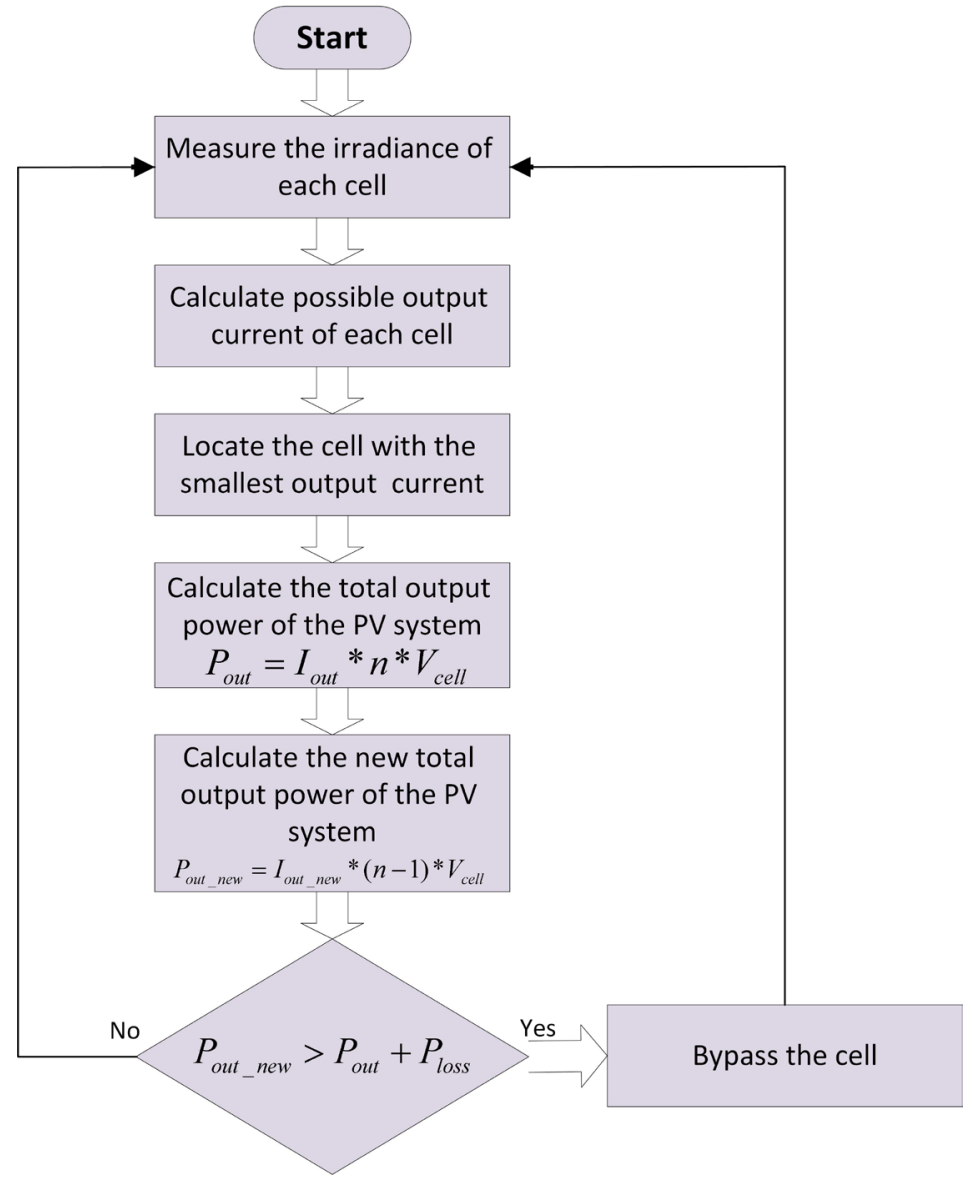

Figure 4. The flowchart of the proposed algorithm.

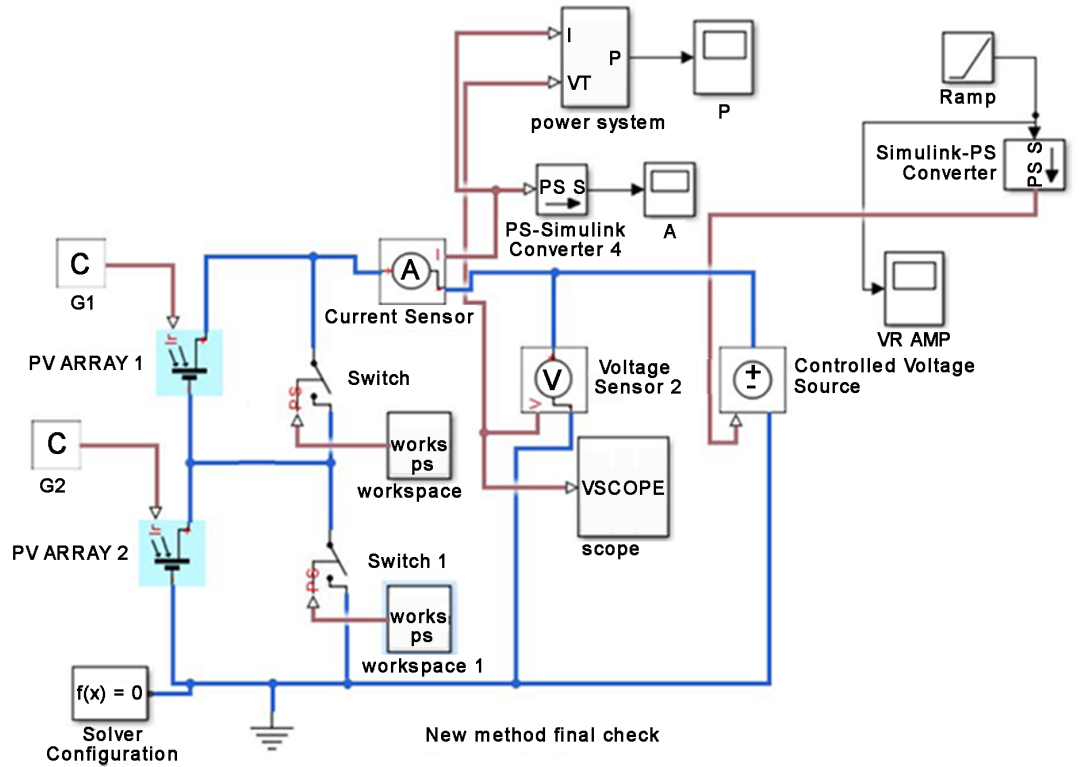

Figure 5. The simulated PV system for testing the proposed algorithm.

due to the convenience of this load for Simulink simulations. The simulated ambient temperature is 25 degrees Celsius. The simulated output power of the PV 
Table 3. The simulated output power of the PV system for different irradiance conditions operated by the proposed algorithm.

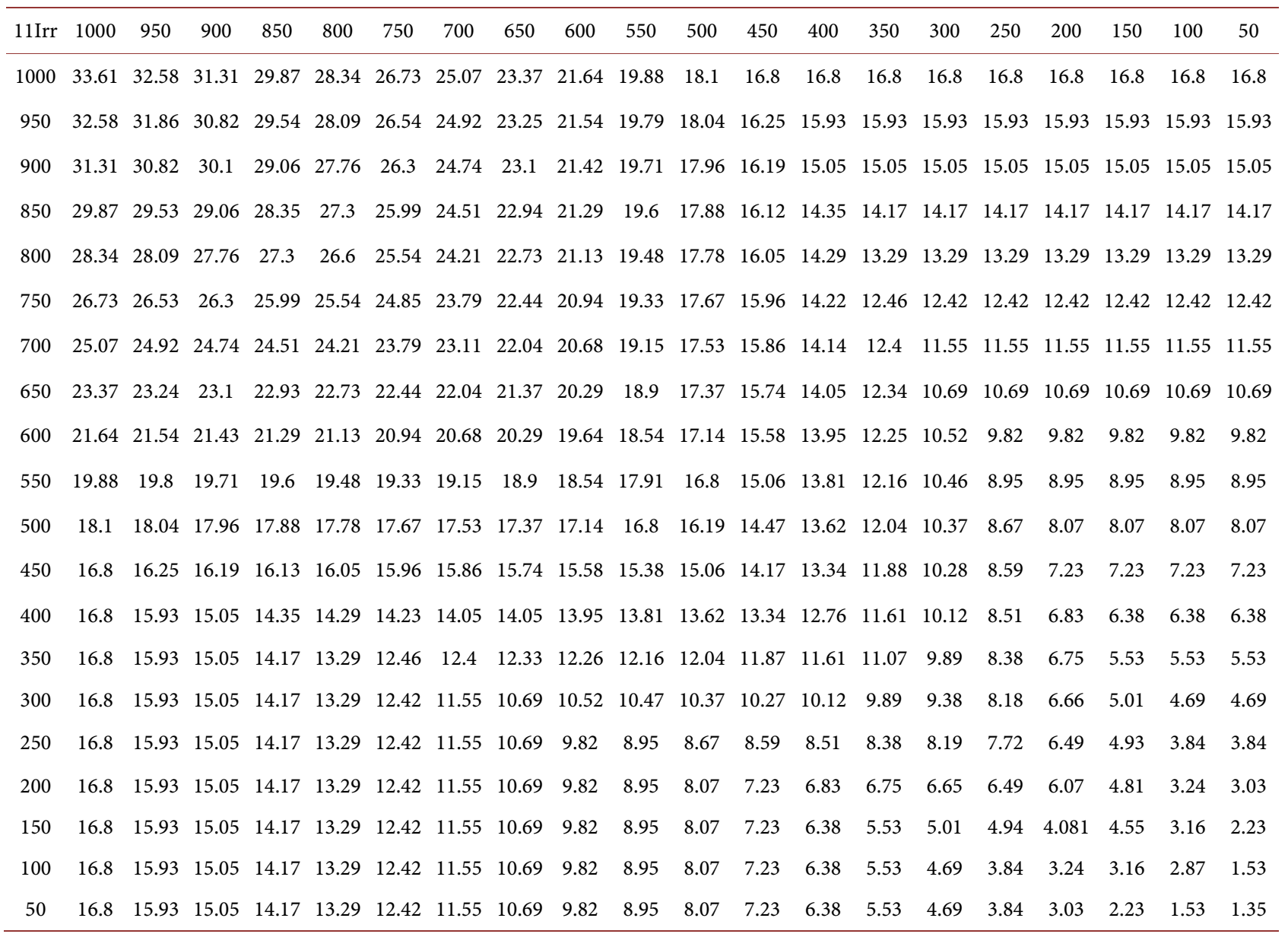

system for different irradiance conditions is shown in Table 3 . It can be seen from Table 3 that the algorithm actually works and improves the efficiency of the PV system. The algorithm becomes more efficient when the number of series connected cells/modules is increased.

\section{Conclusions}

The paper presents new MPPT algorithm for partial shading of series connected PV cells/modules. The algorithm performs active bypassing of the shaded cells that decrease the total output power of the PV system.

By performing extensive simulation of different shading conditions, the algorithm was tested for two series connected cells. It was shown that algorithm works and increases the output power under partial shading conditions. Furthermore, the algorithm becomes more efficient when the number of cells is increased. Therefore, it should be used in large PV installations.

\section{References}

[1] Lim, L.I.H., Ye, Z., Ye, J.Y., Yang, D.Z. and Du, H. (2015) A Linear Identification of 
Diode Models from Single I-V Characteristics of PV Panels. IEEE Transactions on Industrial Electronics, 62, 4181-4193. https://doi.org/10.1109/TIE.2015.2390193

[2] Reis, F., Guerreiro, C., Batista, F., Pimentel, T., Pravettoni, M., Wemans, J., Sorasio, G. and Brito, M.C. (2015) Modeling the Effects of Inhomogeneous Irradiation and Temperature Profile on CPV Solar Cell Behavior. IEEE Journal of Photovoltaics, 5, 112-122. https://doi.org/10.1109/JPHOTOV.2014.2358080

[3] Spertino, F. and Akilimali, J.S. (2009) Are Manufaturing I-V Mismatch and Reverse Currents Key Factors in Large Photovoltaic Arrays? IEEE Transactions on Industrial Electronics, 56, 4520-4531. https://doi.org/10.1109/TIE.2009.2025712

[4] Patel, H. and Agarwal, V. (2008) MATLAB-Based Modeling to Study the Effects of Partial Shading on PV Array Characteristics. IEEE Transactions on Energy Conversion, 23, 302-310. https://doi.org/10.1109/TEC.2007.914308

[5] Ghitas, A.E. and Sabry, M. (2006) A Study of the Effect of Shadowing Location and Area on the Si Solar Cell Electrical Parameters. Vacuum, 81, 475-478. https://doi.org/10.1016/j.vacuum.2006.07.001

[6] Drif, M., Perez, P.J., Aguilera, J. and Aguilar, J.D. (2008) A New Estimation Method of Irradiance on a Partially Shaded PV Generator in Grid-Connected Photovoltaic Systems. Renewable Energy, 33, 2048-2056. https://doi.org/10.1016/j.renene.2007.12.010

[7] Maki, A. and Valkealahti, S. (2012) Power Loss in Long String and Parallel Connected Short Strings of Series-Connected Silicon-Based Photovoltaic Modules Due to Partial Shading Conditions. IEEE Transactions on Energy Conversion, 27, 173-183. https://doi.org/10.1109/TEC.2011.2175928

[8] Paraskevadaki, E.V. and Papathanassiou, S.A. (2011) Evaluation of MPP Voltage and Power of Mc-Si PV Modules in Partial Shading Conditions. IEEE Transactions on Energy Conversion, 26, 923-932. https://doi.org/10.1109/TEC.2011.2126021

[9] Mastromauro, R.A., Liserre, M. and Dell'Aquila, A. (2012) Control Issues in Single-Stage Photovoltaic Systems: MPPT, Current and Voltage Control. IEEE Transactions on Industrial Informatics, 8, 241-254. https://doi.org/10.1109/TII.2012.2186973

[10] Ishaque, K., Salam, Z., Taheri, H., et al. (2011) Maximum Power Point Tracking for PV System under Partial Shading Condition via Particle Swarm Optimization. 2011 IEEE Applied Power Electronics Colloquium (IAPEC 2011), Johor Bahru, 18-19 April 2011. https://doi.org/10.1109/IAPEC.2011.5779866

[11] Petrone, G., Spagnuolo, G., Teodorescu, R., et al. (2008) Reliability Issues in Photovoltaic Power Processing Systems. IEEE Transactions on Industrial Electronics, 55, 2569-2580. https://doi.org/10.1109/TIE.2008.924016

[12] Jeddi, N. and El Amraoui Ouni, L. (2014) Comparative Study of MPPT Techniques for PV Control Systems. International Conference on Electrical Sciences and Technologies in Maghreb, Tunis, 3-6 November 2014, 1-7. https://doi.org/10.1109/CISTEM.2014.7077034

[13] Raj, J.S.C.M. and Jeyakumar, A.E. (2014) A Novel Maximum Power Point Tracking Technique for Photovoltaic Module Based on Power Plane Analysis of I-V Characteristics. IEEE Transactions on Industrial Electronics, 61, 4734- 4745. https://doi.org/10.1109/TIE.2013.2290776

[14] Sera, D., Teodorescu, R., Hantschel, J. and Knoll, M. (2008) Optimized Maximum Power Point Tracker for Fast-Changing Environmental Conditions. IEEE Transactions on Industrial Electronics, 55, 1017-1026. https://doi.org/10.1109/ISIE.2008.4677275 
[15] Vinay, P. and Mathews, M.A. (2014) Modelling and Analysis of Artificial Intelligence Based MPPT Techniques for PV Applications. International Conference on Advances in Green Energy (ICAGE), Thiruvananthapuram, 17-18 December 2014, 56-65.

[16] Chiu, C.-S. and Ouyang, Y.-L. (2011) Robust Maximum Power Tracking Control of Uncertain Photovoltaic Systems: A Unified T-S Fuzzy Model-Based Approach. IEEE Transactions on Control Systems Technology, 19, 1516-1526. https://doi.org/10.1109/TCST.2010.2093900

[17] Chikh, A. and Chandra, A. (2015) An Optimal Maximum Power Point Tracking Algorithm for PV Systems with Climatic Parameters Estimation. IEEE Transactions on Sustainable Energy, 6, 644-652. https://doi.org/10.1109/TSTE.2015.2403845

[18] Uoya, M. and Koizumi, H. (2015) A Calculation Method of Photovoltaic Array's Operating Point for MPPT Evaluation Based on One-Dimensional Newton-Raphson Method. IEEE Transactions on Industry Applications, 51, 567-575.

https://doi.org/10.1109/TIA.2014.2326083

[19] Bizzarri, F., Bongiorno, M., Gruosso, G. and Gajani, G.S. (2013) Model of Photovoltaic Power Plants for Performance Analysis and Production Forecast. IEEE Transactions on Sustainable Energy, 4, 278-285. https://doi.org/10.1109/TSTE.2012.2219563

[20] York, B., Yu, W. and Lai, J.-S. (2013) An Integrated Boost Resonant Converter for Photovoltaic Applications. IEEE Transactions on Power Electronics, 28, 1999-1207. https://doi.org/10.1109/TPEL.2012.2207127

[21] Li, W.H. and He, X.N. (2011) Review of Nonisolated High-Step-Up DC/DC Converters in Photovoltaic Grid-Connected Applications. IEEE Transactions on Industrial Electronics, 58, 364-369. https://doi.org/10.1109/TIE.2010.2049715

[22] Zbeeb, A., Devabhaktuni, V. and Sebak, A. (2009) Improved Photovoltaic MPPT Algorithm Adapted for Unstable Atmospheric Conditions and Partial Shading. 2009 International Conference on Clean Electrical Power, Capri, 9-11 June 2009, 320-323. https://doi.org/10.1109/ICCEP.2009.5212035

[23] Karatepe, E., Hiyama, T., Boztepe, M. and Çolak, M. (2008) Voltage Based Power Compensation System for Photovoltaic Generation System under Partially Shaded Insolation Conditions. Energy Conversion and Management, 49, 2307-2316. https://doi.org/10.1016/j.enconman.2008.01.012

[24] Patel, H. and Agarwal, V. (2008) Maximum Power Point Tracking Scheme for PV Systems Operating under Partially Shaded Conditions. IEEE Transactions on Industrial Electronics, 55, 1689-1698. https://doi.org/10.1109/TIE.2008.917118

[25] Tat Luat, N. and Kay-Soon, L. (2010) A Global Maximum Power Point Tracking Scheme Employing DIRECT Search Algorithm for Photovoltaic Systems. IEEE Transactions on Industrial Electronics, 57, 3456-3467. https://doi.org/10.1109/TIE.2009.2039450

[26] Kobayashi, K., Takano, I. and Sawada, Y. (2006) A Study of a Two Stage Maximum Power Point Tracking Control of a Photovoltaic System under Partially Shaded Insolation Conditions. Solar Energy Mater. Solar Cells, 90, 2975-2988. https://doi.org/10.1016/j.solmat.2006.06.050

[27] Severini, M., et al. (2017) Energy Management with Support of PV Partial Shading Modelling in Micro Grid Environments. Energies, 10, 453. https://doi.org/10.3390/en10040453 
Submit or recommend next manuscript to SCIRP and we will provide best service for you:

Accepting pre-submission inquiries through Email, Facebook, LinkedIn, Twitter, etc. A wide selection of journals (inclusive of 9 subjects, more than 200 journals)

Providing 24-hour high-quality service

User-friendly online submission system

Fair and swift peer-review system

Efficient typesetting and proofreading procedure

Display of the result of downloads and visits, as well as the number of cited articles Maximum dissemination of your research work

Submit your manuscript at: http://papersubmission.scirp.org/

Or contact jpee@scirp.org 